\title{
Relationships between otolith size and fish size in some mesopelagic and bathypelagic species from the Mediterranean Sea (Strait of Messina, Italy)
}

\author{
PIETRO BATTAGLIA ${ }^{1}$, DANILO MALARA ${ }^{1}$, TERESA ROMEO ${ }^{1}$ \\ and FRANCO ANDALORO ${ }^{2}$ \\ ${ }^{1}$ ISPRA (Higher Institute for Environmental Protection and Research), Laboratory of Milazzo, Via dei Mille 44, 98057 \\ Milazzo, Italy. E-mail: pboceano@libero.it \\ ${ }^{2}$ ISPRA, Palermo, c/o Residence Marbela, Via Salvatore Puglisi 9, 98143 Palermo, Italy.
}

\begin{abstract}
SUMMARY: The length-weight relationships and the regressions between otolith size (length and width) and fish length of some mesopelagic and bathypelagic fishes living in the central Mediterranean Sea were provided. Images and morphological description of otoliths (sagittae) from 16 species belonging to the families of Gonostomatidae (1), Microstomatidae (2), Myctophidae (8), Phosichthyidae (2), Sternoptychidae (2) and Stomiidae (1) were given. The length-weight relationship showed an isometric growth in 13 species. No differences between right and left otolith sizes were detected by $t$-test, so a single linear regression was plotted against standard length (SL) for otolith length (OL) and otolith width (OW). Data fitted well to the regression model for both $\mathrm{OL}$ and $\mathrm{OW}$ to $\mathrm{SL}$, for each species $\left(\mathrm{R}^{2}>0.8\right)$. These relationships offer a helpful tool in feeding studies and also provide support to palaeontologists in their research on fish fossils.
\end{abstract}

Keywords: mesopelagic fishes, bathypelagic fishes, otolith, fish-otolith sizes, length-weight relationship, Mediterranean Sea.

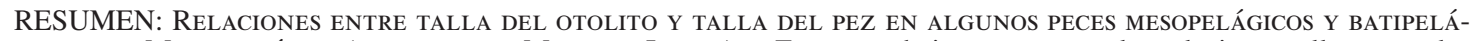
gicos del Mediterráneo (estrecho de Messina, Italia). - En este trabajo se presentan las relaciones talla-peso y las regresiones entre la talla del otolito (longitud y anchura) y la talla del pez (SL) para algunos peces meso y batipelágicos que viven en el Mediterráneo central. Se incluyen imágenes y descripciones morfológicas de los otolitos (sagittae) de 16 especies de las familias Gonostomatidae (1), Microstomatidae (2), Myctophidae (8), Phosichthyidae (2), Sternoptychidae (2) y Stomiidae (1). La relación talla-peso muestra un crecimiento isométrico en 13 especies. No se encontraron diferencias relevantes (t-test) entre la talla del otolito derecho e izquierdo, por lo que se representó una sola regresión lineal entre la longitud estándar y los siguientes parámetros: longitud de otolite $(\mathrm{OL})$ y la anchura $(\mathrm{OW})$. Los datos se ajustaron bien al modelo de regresión lineal para OL y OW, para todas las especies $\left(\mathrm{R}^{2}>0.8\right)$. Las relaciones obtenidas puede ser utilizadas como instrumento en estudios de alimentación y para sustentar estudios de paleontología sobre peces fósiles.

Palabras clave: peces mesopelágicos, peces batipelágicos, otolito, pez-otolito, relación talla-peso, Mediterráneo.

\section{INTRODUCTION}

Mesopelagic and bathypelagic fishes are species usually living in mid-water masses (Salvanes and Kristoffersen, 2001), having a large vertical distribution (Gjøsaeter and Kawaguchi, 1980) and playing an important ecological role in the energy transfer from epipelagic waters to deep environments. In fact, they carry out large diel vertical migrations, moving to- wards the upper layers at night to feed on plankton or micronekton and coming back to deeper waters during the daytime to avoid predation (Marshall, 1960).

Mid-water fishes are a key component of the pelagic nekton and form a large fraction of the deep-scattering layer (DSL) (Benoit-Bird and Au, 2003). The high biomass of mesopelagic and bathypelagic fish communities in all oceans, especially in subtropical and tropical seas (Gjøsaeter and Kawaguchi, 1980; Mann, 1984; 
Lam and Pauly, 2005), is an important food resource in the marine trophic web.

Studies on feeding behaviour have confirmed the mid-water species to be a primary trophic source for commercially important pelagic fishes such as tunas, mackerels and billfishes (Alverson, 1963; Abrams et al., 1996; Hassani et al., 1997; Lebourges-Dhaussy et al., 2000; Moteki et al., 2001; Consoli et al., 2008). Moreover, several other predators, such as marine mammals (Hassani et al., 1997; Pauly et al., 1998; Springer et al., 1999; Dolar et al., 2003; Ohizumi et al., 2003), seabirds (Springer et al., 1999) and cephalopods (Marabello et al., 1996; Watanabe et al., 2004), rely on these food resources.

However, during feeding studies, the identification and quantification of these preys is frequently a difficult task: in most cases specimens are already partially or totally digested and the hard remains in stomachs, intestines, faeces and scats are the only diagnostic features that can be considered. In particular, otoliths are quite resistant to the digestion and they are an important tool for prey classification in several dietary studies (Granadeiro and Silva, 2000; Pierce and Boyle, 1991; Pierce et al., 1991). Furthermore, the diet analysis of marine mammals and sea birds requires non-invasive methods, so the examination of sagittae from faeces and regurgitated digestive pellets is often the only way to recognize the preys (Pierce and Boyle, 1991; Pierce et al., 1991; Duffy and Laurenson, 1983; Johnstone et al., 1990). Their importance is also documented in stomach analysis of cephalopods that use their beaks to chop preys (e.g. Watanabe et al., 2004), making them identifiable only by otolith determination.

For these reasons and thanks to their high interspecific variability, several keys and identification guides on fish otoliths have been published (Smale et al., 1995; Campana, 2004; Lombarte et al., 2006; Tuset et al., 2008). To better understand the real role of fish preys' energy contribution to a predator diet, it is important to estimate their biomass and their numerical abundance. The rebuilding of body size and prey biomass from otolith measurement is possible by applying a back-calculation: a relationship between fish length and otolith size has been widely demonstrated in many fishes (Wyllie Echeverria, 1987; Gamboa, 1991; Granadeiro and Silva, 2000; Harvey et al. 2000; Waessle et al., 2003).

Moreover, the resistance of otoliths to deterioration, due to their particular calcareous structure (a concretion of calcium carbonate and other salts deposited in a protein matrix), made it possible to use them in paleontological studies. Fossil otoliths are found in a wide spectrum of sedimentary environments and are common in many marine sediments (Nolf, 1995). By comparing them to recent reference collections, many authors have made an important contribution to knowledge of the taxonomic status of the ancient fauna of the planet and to the validity of otolith-based fossil fish species (e.g. Nolf, 1985, 1995; Girone et al., 2006).

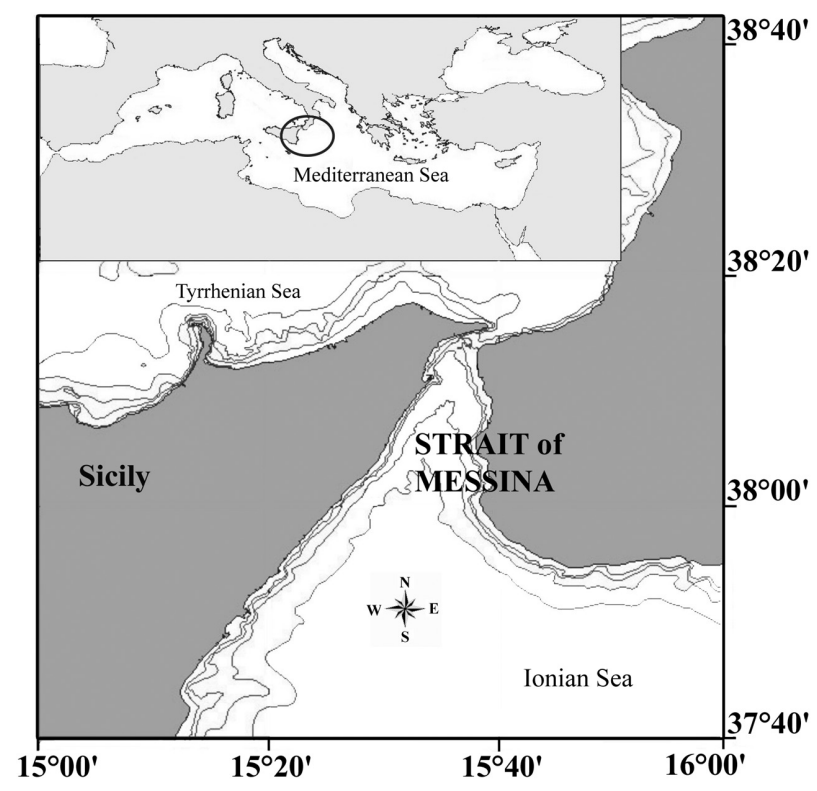

FIG. 1. - Map of the Mediterranean Sea showing the location of the study area in the Strait of Messina.

Though their reliability and scale are proportional to the availability of information on description of current otolith species, otolith data are widely used in the fields of paleoecology, paleobathymetry, paleoclimatology, paleobiogeography and biostratigraphy (Nolf, 1995).

The aim of this paper is to provide data about the relationship between otolith size (length and width) and fish length as well as between fish weight and fish length of some mesopelagic and bathypelagic fishes living in the central Mediterranean Sea. As little information is available on these fishes, in spite of their role in the food web, this paper fills an important gap. The data offer a helpful tool for feeding studies and also provide support to palaeontologists in their research on fossils. We also supply otolith images from these fishes, in order to improve and facilitate their identification. According to the terminology used by Tuset et al. (2008), we present a brief description of the sagittae for the species that were not reported in this last atlas, which offered the first major description of otoliths of recent Mediterranean fish species.

\section{MATERIALS AND METHODS}

Fishes stranded along the coasts of the Strait of Messina in the central Mediterranean Sea (Fig. 1) were collected in 2007-2009. The Strait of Messina joins the Tyrrhenian and the Ionian Basins together and its depth changes from about $2000 \mathrm{~m}$ off the southern Ionian part to about $80 \mathrm{~m}$ in the central part, while it reaches $300 \mathrm{~m}$ in the Tyrrhenian versant.

This area is known for its strong upwelling currents caused by different tidal phases of the two abovementioned basins and their intensity is regulated by lunar phases (Mazzarelli, 1909; Vercelli, 1925; De 
TABLE 1. - List of the mesopelagic species sampled in the Strait of Messina. Number of individuals (n), ranges of fish lengths (SL) and weights (W) are given.

\begin{tabular}{|c|c|c|c|c|c|}
\hline Species & Common name & Family & $\mathrm{n}$ & SL range $(\mathrm{mm})$ & $\mathrm{W}$ range $(\mathrm{g})$ \\
\hline Argyropelecus hemigymnus Cocco, 1829 & Half-naked hatchetfish & Sternoptychidae & 138 & $8.3-41.0$ & $0.01-1.75$ \\
\hline Ceratoscopelus maderensis (Lowe, 1839) & Madeira lantern fish & Myctophidae & 15 & $14.5-68.7$ & $0.04-4.97$ \\
\hline Chauliodus sloani Bloch \& Schneider, 1810 & Sloane's viperfish & Stomiidae & 83 & $68.0-203.0$ & $0.60-116.20$ \\
\hline Diaphus holti Tåning, 1918 & Small lantern fish & Myctophidae & 23 & $13.5-53.0$ & $0.06-2.66$ \\
\hline Electrona risso $($ Cocco, 1829$)$ & Chubby flashlight fish & Myctophidae & 233 & $9.6-50.0$ & $0.01-3.95$ \\
\hline Gonostoma denudatum Rafinesque, 1810 & & Gonostomatidae & 65 & $26.5-131.2$ & $0.12-15.90$ \\
\hline Gonychthys cocco $($ Cocco, 1829$)$ & & Myctophidae & 16 & $23.5-47.7$ & $0.14-1.17$ \\
\hline Hygophum benoiti (Cocco, 1838) & Benoit's lanternfish & Myctophidae & 288 & $16.0-58.0$ & $0.04-3.37$ \\
\hline Hygophum hygomii (Lütken, 1892) & Bermuda lantern fish & Myctophidae & 45 & $16.8-30.2$ & $0.05-0.47$ \\
\hline Ichthyococcus ovatus Cocco, 1838 & Lightfish & Phosichthyidae & 40 & $16.9-38.1$ & $0.11-1.27$ \\
\hline Lampanyctus pusillus (Johnson, 1890) & Pygmy lanternfish & Myctophidae & 27 & $7.8-41.1$ & $0.01-0.82$ \\
\hline Maurolicus muelleri (Gmelin, 1789) & Pearlsides & Sternoptychidae & 93 & $12.0-50.0$ & $0.02-2.10$ \\
\hline Microstoma microstoma Risso, 1810 & Slender argentine & Microstomatidae & 49 & $18.3-186.3$ & $0.03-27.40$ \\
\hline Myctophum punctatum Rafinesque, 1810 & Spotted lanternfish & Myctophidae & 82 & $20.3-73.7$ & $0.06-5.72$ \\
\hline Nansenia oblita (Facciolà, 1887) & & Microstomatidae & 80 & $15.3-78.0$ & $0.04-4.66$ \\
\hline Vinciguerria attenuata (Сосco, 1838) & Slender lightfish & Phosichthyidae & 136 & $15.3-36.5$ & $0.03-0.65$ \\
\hline
\end{tabular}

Domenico, 1987). The strong hydrodynamism and the particular meteorological conditions (strong wind from the SE) are the main causes of mesopelagic and deep fauna stranding in this area (Mazzarelli, 1909; Genovese et al., 1971; Berdar et al., 1977; Spalletta et al., 1995).

The biological material was collected along the $\mathrm{Si}$ cilian coast of the Strait of Messina before the sunrise, in order to avoid the competition of seabirds, ants and wasps and the sun's drying effect.

Specimens were identified following Whitehead et al. (1984-1986), photographed with a camera, measured by calliper to the nearest $0.1 \mathrm{~mm}$ (following Tortonese, 1970) and weighed to the nearest $0.01 \mathrm{~g}$. In most cases the caudal fin was damaged, so the standard length (SL) in place of the total length (TL) was considered. Sagittal otoliths were removed, cleaned and stored dry with a code number.

Lengths of sagittae (OL) were determined by an ocular micrometer mounted on a Zeiss Stemi 2000-C stereomicroscope and were recorded as the greatest distance measured from the anterior tip to the posterior edge, parallel to the sulcus (Harvey et al., 2000). The width of every sagitta (OW) was determined by considering the greatest distance from the dorsal otolith edge to the ventral one, perpendicular to the sulcus.

Length-weight relationship for every species was also described using the potential function:

$$
\mathrm{W}=a * \mathrm{SL}^{b}
$$

where $\mathrm{W}$ is the total weight, SL the standard length, $a$ the intercept of the regression line and $b$ the regression coefficient, indicating the isometric growth when equal to 3 (Anderson and Neumann, 1996). Parameters $a$ and $b$ were estimated by transforming (ln) the equation by linear regression. To check the theoretical isometric $(b$ $=3$ ) or allometric growth $(b \neq 3)$, Student's $t$-test (Snedecor and Cochran, 1967) was employed.

The relationships between otolith and fish sizes were determined using a least-squares linear regres- sion for the following parameters: otolith length (OL) - fish length (SL) and otolith width $(\mathrm{OW})$ - fish length (SL). These equations were first calculated for both left and right otoliths and the $t$-test was used to check any difference between regressions. The regression coefficients were compared and when significant differences $(\mathrm{p}<0.05)$ were not found, the $H_{0}$ hypothesis $\left(b_{\text {rigth }}=\right.$ $b_{\text {left }}$ ) was accepted. When the equations did not differ statistically, a single linear regression was reported for each parameter (OL; OW) and species, by choosing randomly one right or left otolith from each specimen. The significance of the linear regressions was verified using the $F$-test.

\section{RESULTS}

Overall 16 mesopelagic and bathypelagic species belonging to the families Gonostomatidae (1), Microstomatidae (2), Myctophidae (8), Phosichthyidae (2), Sternoptychidae (2) and Stomiidae (1) were studied (Table 1). In Table 1 the sample size (n), SL range $(\mathrm{mm})$ and $\mathrm{W}$ range $(\mathrm{g})$ for each species are also reported. The highest number of specimens was recorded for Benoit's lanternfish, Hygophum benoiti $(\mathrm{n}=288)$, and the chubby flashlight fish, Electrona risso $(\mathrm{n}=233)$.

\section{Otoliths' morphology}

Representative otoliths for each species are shown in Figures 2 and 3. A brief description is also provided for the species that were not reported in the atlas published by Tuset et al. (2008), according to the terminology used by these authors:

i) Microstomatidae. Lanceolated anterior region and round to peaked posterior one. Broad and pointed rostrum. Lobed dorsal margin and lobed to irregular ventral margin. Median ostial sulcus acusticus, tubular ostium and tubular straight cauda. Microstoma microstoma (Fig. 2B), spindle-shaped otolith; Nansenia oblita (Fig. 2C), spindle-shaped to sagittiform otolith.

ii) Myctophidae. Discoidal otolith, with double- 


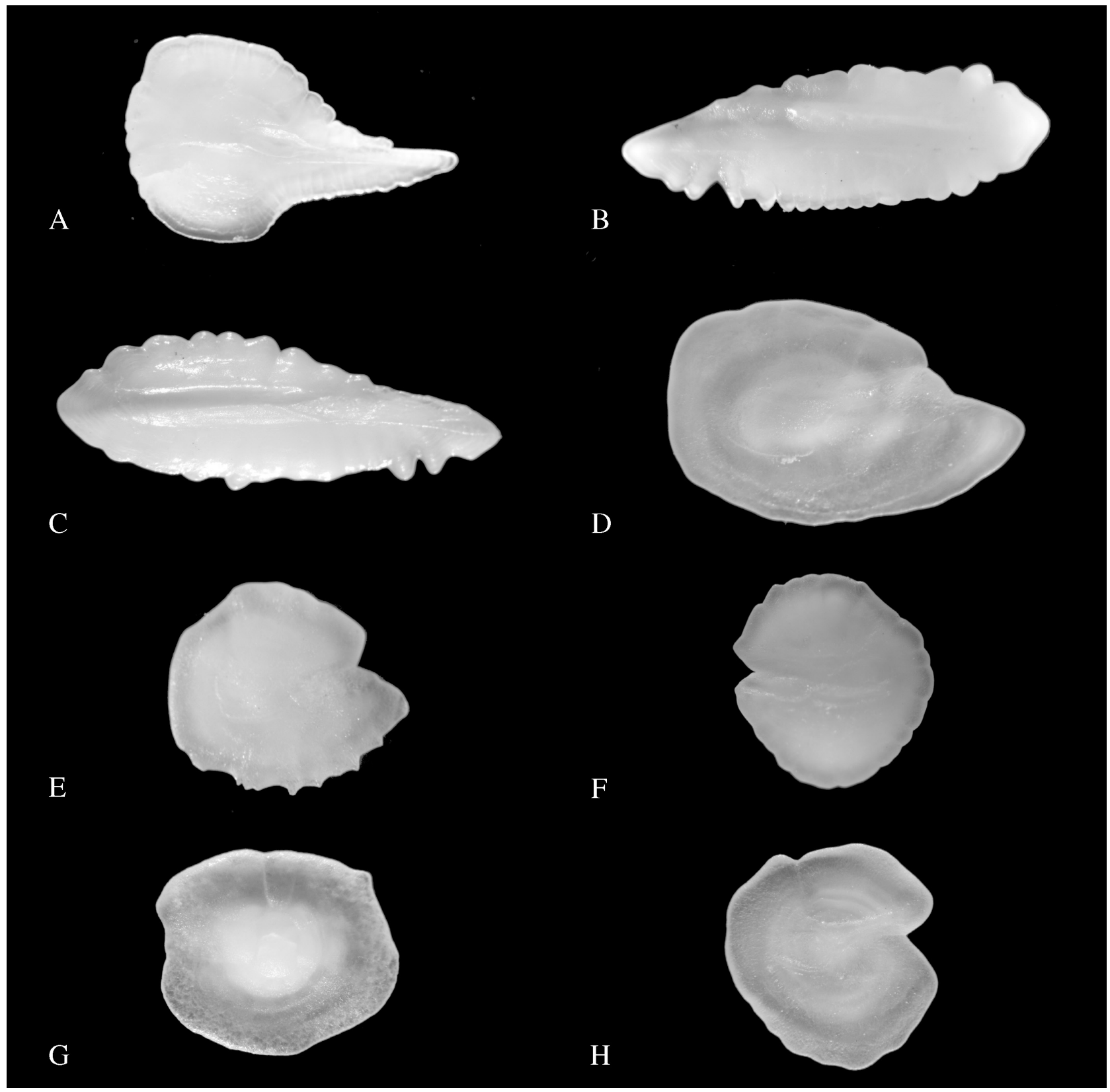

FIG. 2. - A, Gonostoma denudatum ( $\mathrm{SL}=118.2 \mathrm{~mm} ; \mathrm{W}=8.10 \mathrm{~g}$ ), left otolith (OL = $4.18 \mathrm{~mm}$; OW = $2.59 \mathrm{~mm})$; B, Microstoma microstoma $(\mathrm{SL}=146.0 \mathrm{~mm} ; \mathrm{W}=18.09 \mathrm{~g})$, right otolith $(\mathrm{OL}=5.37 \mathrm{~mm} ; \mathrm{OW}=1.92 \mathrm{~mm}) ; \mathrm{C}$, Nansenia oblita $(\mathrm{SL}=78.0 \mathrm{~mm} ; \mathrm{W}=4.66 \mathrm{~g})$, left otolith $(\mathrm{OL}=4.01 \mathrm{~mm} ; \mathrm{OW}=1.44 \mathrm{~mm}) ; \mathrm{D}$, Ceratoscopelus maderensis $(\mathrm{SL}=62.5 \mathrm{~mm} ; \mathrm{W}=2.95 \mathrm{~g})$, left otolith $(\mathrm{OL}=2.93 \mathrm{~mm} ; \mathrm{OW}=1.70 \mathrm{~mm}) ;$ E, Diaphus holti $(\mathrm{SL}=53.0 \mathrm{~mm} ; \mathrm{W}=2.66 \mathrm{~g})$, left otolith $(\mathrm{OL}=3.09 \mathrm{~mm} ; \mathrm{OW}=2.93 \mathrm{~mm}) ; \mathrm{F}$, Electrona risso $(\mathrm{SL}=48.5 \mathrm{~mm} ; \mathrm{W}=3.37 \mathrm{~g})$, right otolith $(\mathrm{OL}=3.29 \mathrm{~mm} ; \mathrm{OW}=3.64 \mathrm{~mm}) ; \mathrm{G}$, Gonichthys cocco $(\mathrm{SL}=45.5 \mathrm{~mm} ; \mathrm{W}=1.10 \mathrm{~g})$, right otolith $(\mathrm{OL}=1.27 \mathrm{~mm} ; \mathrm{OW}=1.09$ $\mathrm{mm}) ; \mathrm{H}$, Hygophum benoiti $(\mathrm{SL}=51.2 \mathrm{~mm} ; \mathrm{W}=2.40 \mathrm{~g})$, left otolith $(\mathrm{OL}=1.86 \mathrm{~mm} ; \mathrm{OW}=1.96 \mathrm{~mm})$.

peaked anterior region and round posterior one. Short and broad rostrum. Median ostial sulcus acusticus. $D i$ aphus holti (Fig. 2E), serrate ventral margin and sinuate dorsal one; Funnel-like ostium and round-oval cauda. Electrona risso (Fig. 2F), sinuate to crenate margins; oval ostium and round-oval cauda. Hygophum benoiti (Fig. 2H), sinuate margins; funnel-like ostium and round-oval cauda. Hygophum hygomii (Fig. 3A), lobed margins; funnel-like ostium and slightly curved tubular cauda. Lampanyctus pusillus (Fig. 3B), the anterior re- gion is not double-peaked but approximately flattened; entire margins and very short rostrum; rectangular ostium and a round-oval cauda.

iii) Phosichthyidae. Ichthyococcus ovatus (Fig. 3D), tall and pseudo-triangular otolith, notched anterior region with lobate margin, round posterior region with entire to sinuate margins; rostrum is elongated; median pseudo-ostial sulcus acusticus, elliptic ostium and roundoval cauda. Vinciguerria attenuata (Fig. 3E), pyriform otolith with peaked anterior region and round posterior 


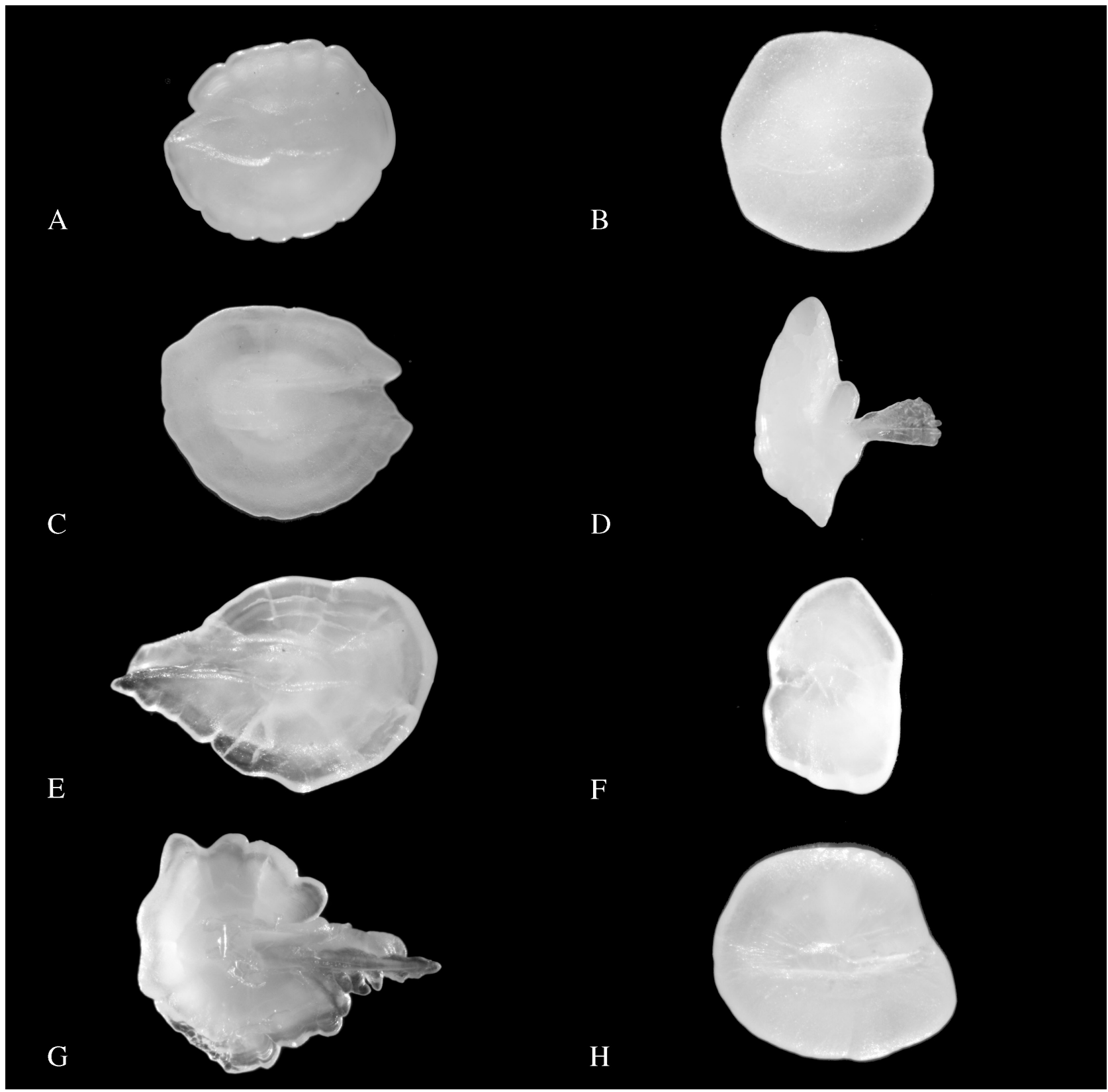

FIG. 3. - A, Hygophum hygomii $(\mathrm{SL}=28.7 \mathrm{~mm} ; \mathrm{W}=0.37 \mathrm{~g})$, right otolith $(\mathrm{OL}=1.69 \mathrm{~mm}$; $\mathrm{OW}=1.48 \mathrm{~mm})$; B, Lampanyctus pusillus (SL $=37.4 \mathrm{~mm} ; \mathrm{W}=0.51 \mathrm{~g})$, left otolith $(\mathrm{OL}=1.05 \mathrm{~mm} ; \mathrm{OW}=1.05 \mathrm{~mm}) ; \mathrm{C}$, Myctophum punctatum $(\mathrm{SL}=73.7 \mathrm{~mm} ; \mathrm{W}=5.72 \mathrm{~g})$, left otolith $(\mathrm{OL}=3.29 \mathrm{~mm} ; \mathrm{OW}=2.69 \mathrm{~mm}) ; \mathrm{D}$, Ichthyococcus ovatus $(\mathrm{SL}=35.7 \mathrm{~mm} ; \mathrm{W}=1.06 \mathrm{~g})$, left otolith $(\mathrm{OL}=3.16 \mathrm{~mm} ; \mathrm{OW}=3.88 \mathrm{~mm}) ; \mathrm{E}$, Vinciguerria attenuata $(\mathrm{SL}=35.8 \mathrm{~mm} ; \mathrm{W}=0.42 \mathrm{~g})$, rigth otolith $(\mathrm{OL}=1.39 \mathrm{~mm} ; \mathrm{OW}=0.94 \mathrm{~mm}) ; \mathrm{F}$, Argyropelecus hemigymnus $(\mathrm{SL}=34.0$ $\mathrm{mm} ; \mathrm{W}=0.87 \mathrm{~g})$, rigth otolith $(\mathrm{OL}=0.60 \mathrm{~mm} ; \mathrm{OW}=0.90 \mathrm{~mm}) ; \mathrm{G}$, Maurolicus muelleri $(\mathrm{SL}=45.0 \mathrm{~mm} ; \mathrm{W}=1.33 \mathrm{~g})$, left otolith $(\mathrm{OL}=2.05$ $\mathrm{mm}$; OW = $1.61 \mathrm{~mm}) ; \mathrm{H}$, Chauliodus sloani $(\mathrm{SL}=201.9 \mathrm{~mm} ; \mathrm{W}=18.50 \mathrm{~g})$, left otolith $(\mathrm{OL}=0.99 \mathrm{~mm} ; \mathrm{OW}=0.89 \mathrm{~mm})$.

one; elongated and pointed rostrum: sagitta has irregular margins, a median ostial sulcus acusticus, a funnel-like ostium and a tubular straight cauda.

\section{Data analysis}

Length-weight relationships and linear regression of otolith length and width against fish length for every species are given in Table 2. Of a total of 16 species, 13 showed an isometric growth since the regression coefficient $b$ did not differ significantly from the theoretical value of 3 . Statistical analysis ( $t$-test) revealed significant differences only for three species, indicating an allometric growth: Hygophum benoiti $(\mathrm{n}=$ 288 , df $=286, \mathrm{p}<0.01)$, H. hygomii $(\mathrm{n}=45$, $\mathrm{df}=43$, $\mathrm{p}<0.001)$, and Vinciguerria attenuata $(\mathrm{n}=136$, $\mathrm{df}=$ $134, \mathrm{p}<0.001)$. High correlation coefficients $\left(R^{2}>0.93\right)$ calculated for the SL-W relationship were obtained in 15 species, with the exception of Chauliodus sloani, which showed a lower value $\left(\mathrm{R}^{2}=0.833\right)$. 


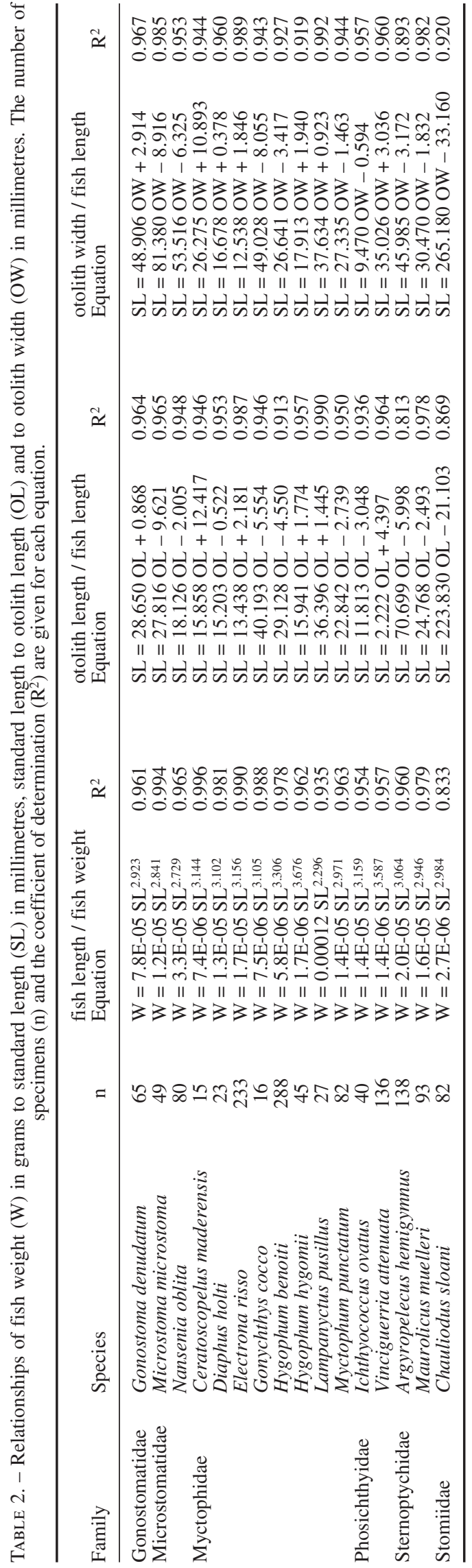

In the analysis of morphometric parameters (otolith length and width) against SL, no considerable differences between right and left otoliths were detected by the $t$-test, so a single linear regression was plotted for each parameter. Data fitted well to the regression model for both OL and OW to SL for each species, as demonstrated by the high values of the coefficient of determination. Only the half-naked hatchetfish Argyropelecus hemigymnus showed a $\mathrm{R}^{2}$ value that was considerably lower $\left(\mathrm{R}^{2}=0.813\right)$ than the others.

\section{DISCUSSION}

Otoliths are a powerful taxonomic feature for fish species identification because of their high inter-specific variability in shape. Though the classification of fish preys is facilitated by some reference works (Smale et al., 1995; Campana, 2004; Lombarte et al., 2006; Tuset et al., 2008), only certain geographical areas are covered and the access to reference material remains essential (Santos et al., 2001). Therefore, a fundamental objective of researchers studying the marine predators' feeding habits is to fill the gap of information on the fish otolith morphology and on the estimation of specific equations, which is useful to calculate the size and mass of preys.

The results of the present study respond to this need, providing SL-W, OL-SL and OW-SL relationships for several mesopelagic and bathypelagic species. Despite the importance of these fishes in top predators' diet, their biology and ecology had not been well investigated until today. In fact, owing to their null commercial value, they are not a target of fishing activities and they can only be sampled by organizing appropriate scientific cruises. The opportunity of collecting stranded specimens in the area of Strait of Messina allowed us to study these species at a low cost.

This study provides a useful tool for better understanding the trophic relationships in the Mediterranean food web. The rebuilding of prey biomass from otolith size may help to return the real importance to the Mediterranean mid-water fishes, shedding light on their role in the trophic structure, as pointed out by some feeding studies (Castriota et al., 2007; Falautano et al., 2007; Consoli et al., 2008; Karakulak et al., 2009). However, to this day, the lack of data in these area has not always permitted an appropriate quantification of their prey biomass and classification to species level in the diet of Mediterranean pelagic predators. In fact, quite a high percentage of unidentified mesopelagic fishes and otoliths in swordfish and tuna stomach contents have been recorded (Sinopoli et al., 2004; Falautano et al., 2007; Mostarda et al., 2007; Romeo et al., 2009).

In comparison with other similar studies on the relationship between fish and sagitta sizes (Wyllie Echeverria, 1987; Gamboa, 1991; Granadeiro and Silva, 2000; Harvey et al., 2000; Waessle et al., 2003), this paper supplies additional information by considering both the otolith width (OW) and length (OL). In most cases, the calculation of two equations (OL-SL and OW$\mathrm{SL}$ ) is more suitable, since the tip of the otolith rostrum may be damaged, making it impossible to measure the OL. Moreover, the coefficient of determination of the OW-SL linear regression attained a higher value than in the OL-SL one in the same species (Table 2). 
The otoliths of the investigated species did not show significant differences in size between left and right sagittae, in contrast with the findings of Waessle et al. (2003) in two sciaenid fishes (Micropogonias furnieri and Macrodon ancylodon) and Harvey et al. (2000) in the teleost Lycodes palearis (Zoarcidae). However, Harvey et al. (2000) indicated the small size of the sample as the possible cause of this diversity.

Most published regressions of OL to SL (Wyllie Echeverria, 1987; Gamboa, 1991; Harvey et al., 2000; Waessle et al., 2003) or SL to W relationships (Harvey et al., 2000; Valle et al., 2003; İlkyaz et al., 2008; Mata et al., 2008) concern coastal or commercially important species. Very few data are available on mesopelagic and bathypelagic fishes. As regards the species considered in the present paper, the sternoptychid Maurolicus muelleri has been the most investigated and SL-W and OL-SL relationships for populations living in the Norwegian Sea have been calculated (Rasmussen and Giske, 1994; Salvanes and Stockley, 1996; Kristoffersen, 2007). SL-W relationships for Argyropelecus hemigymnus and $\mathrm{Hy}$ gophum benoiti by specimens collected in the Strait of Messina were provided by Donato et al. (1993) and Potoschi et al. (2003) respectively.

Though all data fitted well with the linear regression (OL-SL and OW-SL) and the potential (SL-W) models, it is advisable to use these equations within the fish size range limits reported in Table 1. In fact, otoliths may slow down the increase in length, increasing only in thickness at the maximum fish size (Williams and Bedford, 1974) or may grow following a curvilinear model in juvenile fishes (Nishimura and Yamada, 1988). In particular, Linkowski (1991) described a change in the otolith growth pattern at a larval size of $12 \mathrm{~mm}$ in the myctophid Ceratoscopelus maderensis and then supplied two different OL-SL regressions for specimens smaller than $12 \mathrm{~mm}$ and for larger ones. Since the individuals of $C$. maderensis collected in the present paper belong to the 14.5-68.7 $\mathrm{mm}$ SL range, the single OL-SL regression reported in Table 2 can be accepted.

Finally, some limitations to the use of biomass reconstruction from otolith size should be taken into account. The growth of individuals belonging to the same species may show some variations for different areas and stocks (Campana and Casselman, 1993; Reichenbacher et al., 2009) or between sexes (Wyllie Echeverria, 1987). Furthermore, otoliths are exposed to chemical and mechanical abrasion in the digestive track of predators (Jobling and Breiby 1986; Granadeiro and Silva, 2000) and their size may be underestimated.

\section{ACKNOWLEDGEMENTS}

We are grateful to Cap. Giovanni Ammendolia for his assistance in collecting specimens and to Prof. Dirk Nolf for his valuable bibliographic material.

\section{REFERENCES}

Abrams, P.A., B.A. Menge, G.G. Mittelbach, D.A. Spiller and P. Yodzis. - 1996. The role of indirect effects in food webs. In: G.A. Polis and K.O. Winemiller (eds), Food Webs. Integration of pattern and dynamics, pp. 371-395. New York, Chapman and Hall.

Alverson, F.G. - 1963. The food of yellowfin and skipjack tunas in the eastern tropical Pacific Ocean, Inter-Am. Trop. Tuna Comm. Bull., 7: 295-396.

Anderson, R.O. and R.M. Neumann. - 1996. Length, weight and associated structural indices. In: B.R. Murphy and D. Wills (eds.), Fisheries Techniques, pp. 447-481. Bethesda, American Fisheries Society.

Benoit-Bird K.J. and W.W.L. Au. - 2003. Echo strength and density structure of Hawaiian mesopelagic boundary community patches. J. Acoust. Soc. Am., 114 (4): 1888-1897.

Berdar, A., G. Cavallaro, G. Giuffrè and A. Potoschi. - 1977. Contributo alla conoscenza dei Pesci spiaggiati lungo il litorale siciliano dello Stretto di Messina. Mem. Biol. Mar. Oceanogr., 7(5-6): 77-87.

Campana, S.E. and J.M. Casselman. - 1993. Stock discrimination using otolith shape analysis. Can. J. Fish. Aquat. Sci., 50: 1062-1083.

Campana, S.E. - 2004. Photographic atlas of fish otoliths of the Northwest Atlantic Ocean, pp. 284. Ottawa, Ontario: NRC Research Press.

Castriota, L., C. Pipitone, S. Campagnuolo, M. Romanelli, A. Potoschi and F. Andaloro. - 2007. Diet of Coryphaena hippurus (Coryphaenidae) associated with FADs in the Ionian and Southern Tyrrhenian Seas. Cybium, 31: 435-441.

Consoli, P., T. Romeo, P. Battaglia, L. Castriota, V. Esposito and F. Andaloro. - 2008. Feeding habits of the albacore tuna Thunnus alalunga (Perciformes, Scombridae) from central Mediterranean Sea. Mar. Biol., 155: 113-120.

De Domenico, E. - 1987. Caratteristiche fisiche e chimiche delle acque nello Stretto di Messina. In: Di Geronimo, Barrier and Mantenat, (eds.), Le Detroit de Messine, Evolution TectonoSedimentaire Recente (Pliocene et Quaternaire) et Environment Actuel. Documents et Travaux de l'IGAL, Paris, 11: 225-235.

Dolar, M.L.L., W.A. Walker, G.L. Kooyman and W.F. Perrin. 2003. Comparative feeding ecology of spinner dolphins (Stenella longirostris) and Fraser's dolphins (Lagenodelphis hosei) in the Sulu Sea. Mar. Mamm. Sci., 19: 1-19.

Donato, A., E. Pizzul, L. Salpietro, M. Specchi and G. Valli. - 1993. Osservazioni sulla biologia di Argyropelecus hemigymnus Cocco (1829) (Osteichthyes, Sternoptychidae). Suppl. Ric. Biol. Selvaggina, 21: 497-505.

Duffy, D.C. and L.J.B. Laurenson. - 1983. Pellets of cape cormorants as indicators of diet. Condor 85: 305-307.

Falautano, M., L. Castriota, M.G. Finoia and F. Andaloro. - 2007. Feeling ecology of little tunny Euthynnus alletteratus in the central Mediterranean Sea. J. Mar. Biol. Ass. U.K., 87: 999-1005.

Genovese, S., A. Berdar and L. Guglielmo. - 1971. Spiaggiamenti di fauna abissale nello Stretto di Messina. Atti Soc. Pelor. Sci., 17: 331-370.

Gamboa, D.A. - 1991. Otolith Size versus Weight and Body-Length Relationships for Eleven Fish Species of Baja California, Mexico. Fish. Bull. U.S., 89: 701-706.

Girone, A., D. Nolf and H. Cappetta. - 2006. Pleistocene fish otoliths from the Mediterranean Basin: a synthesis. Geobios, 39: 651-671.

Gjøsaeter, J. and K. Kawaguchi. - 1980. A review of the world resources of mesopelagic fish. FAO Fish. Tech. Pap., 193, FIRM/ TI93, pp. 151

Granadeiro, J.P. and M.A. Silva. - 2000. The use of otoliths and vertebrae in the identification and size-estimation of fish in predator-prey studies. Cybium, 24: 383-393.

Harvey, J.T., T.R. Loughlin, M.A. Perez and D.S. Oxman. - 2000. Relationship between fish size and otolith length for 63 species of fishes from the eastern north Pacific Ocean. NOAA Tech. Rep. NMFS, 150 , pp. 35.

Hassani, S., L. Antoine and V. Ridoux. - 1997. Diets of albacore, Thunnus alalunga, and dolphins, Delphinus delphis and Stenella coerulaeoalba, caught in the northeast Atlantic albacore drift-net fishery: A progress report. J. Northwest Atl. Fish. Sci., 
22: 119-123.

İlkyaz, A.T., G. Metin, O. Soykan and H.T. Kinacigil. - 2008. Length-weight relationship of 62 fish species from the central Aegean Sea, Turkey. J. Appl. Ichthyol., 24: 699-702.

Jobling, M. and A. Breiby - 1986. The use and abuse of fish otoliths in studies of feeding habits of marine piscivores. Sarsia, 71: 265-274.

Johnstone, I.G., M.P. Harris, S. Wanless and J.A. Graves. - 1990. The usefulness of pellets for assessing the diet of adult shags Phalacrocorax aristotelis. Bird Study, 37: 5-11.

Karakulak, F.S., A. Salman and I.K. Oray. - 2009. Diet composition of bluefin tuna (Thunnus thynnus L. 1758) in the Eastern Mediterranean Sea, Turkey. J. Appl. Ichthyol., in press.

Kristoffersen, J.B. - 2007. Growth rate and relative otolith size in populations of adult Müller's pearlside Maurolicus muelleri. J. Fish Biol., 71: 1317-1330.

Lam, V. and D. Pauly. - 2005. Mapping the global biomass of mesopelagic fishes. Sea Around Us Project Newsletter July/August 30: 4.

Lebourges-Dhaussy, A., E. Marchal, C. Menkès, G. Champalbert and B. Biessy. - 2000. Vinciguerria nimbaria (micronekton), environment and tuna: their relationships in the Eastern Tropical Atlantic. Oceanol. Acta, 23: 515-528.

Linkowski, T.B. - 1991. Otolith microstructure and growth patterns during the early life history of lanternfishes (family Myctophidae). Can. J. Zool., 69: 1777-1792.

Lombarte, A., Ò. Chic, V. Parisi-Baradad, R. Olivella, J. Piera and E. García-Ladona. - 2006. A web-based environment from shape analysis of fish otoliths. The AFORO database (http:// www.cmima.csic.es/aforo/). Sci. Mar., 70: 147-152.

Mann, K.H. - 1984. Fish production in open ocean systems. In: M.J.R. Fasham (ed.), Flows of energy and materials in marine ecosystems. Theory and practice, pp. 435-458. New York, Plenum Press.

Marabello, F., L. Guglielmo, A. Granata and O. Sidoti. - 1996. Studi preliminari sulle abitudini alimentari di Todarodes sagittatus (Cephalopoda) nel Tirreno meridionale. In: G. Albertelli, A. De Maio and M. Piccazzo (eds.), Atti $11^{\circ}$ Congresso AIOL (Ass. It. Oceanol. Limnol.), pp. 271-278. Genova, Italy.

Marshall, N.B. - 1960. Swimbladder structure of deep-sea fishes in relation to their systematics and biology. Disc. Rep., 31: 3-122.

Mata, A.J., J. Morales and L. Márquez. - 2008. Weight-length relationships for 26 demersal fish species of the Spanish SouthAtlantic coastal waters. J. Appl. Ichthyol., 24: 330-333.

Mazzarelli, G. - 1909. Gli animali abissali e le correnti sottomarine dello Stretto di Messina. Riv. Mens. Pesca Idrobiol., 11: 177-218.

Mostarda, E., D. Campo, L. Castrista, V. Esposito, M.P. Scarabello and F. Andaloro. - 2007. Feeling habits of the bullet tuna Auxis rochei in the southern Tyrrhenian Sea. J. Mar. Biol. Ass. U.K., 87: 1007-1012.

Moteki, M., M. Arai, K. Tsuchiya and H. Okamoto. - 2001. Composition of piscine prey in the diet of large pelagic fish in the eastern tropical Pacific Ocean. Fish. Sci., 67: 1063-1074.

Nishimura, A and J. Yamada. - 1988. Geographical differences in early growth of walleye Pollock Theragra chalcogramma, estimated by back-calculation of otolith daily growth increments. Mar. Biol., 97: 459-465.

Nolf, D. - 1985. Handbook of Paleoichthyology. Otolithi piscium. 10 , pp. 141 Stuttgart, Springer Verlag.

Nolf, D. - 1995. Studies on fossil otoliths - the state of the art. In: D.H. Secor, J.M. Dean and S.E. Campana, (eds.). Recent developments in fish otolith research, pp. 513-544. University of South Carolina Press.

Ohizumi, H., T. Kuramochi, T. Kubodera, M. Yoshioka and N. Miyazaki. - 2003. Feeding habits of Dall's porpoises (Phocoenoides dalli) in the subarctic North Pacific and the Bering Sea basin and the impact of predation on mesopelagic micronekton. Deep-Sea Res. I, 50: 593-610.

Pauly, D., A.W. Trites, E. Capuli and V. Christensen. - 1998. Diet composition and trophic levels of marine mammals. ICES J. Mar. Sci., 55: 467-481.

Pierce, G.J. and P.R. Boyle. - 1991. A review of methods for diet analysis in piscivorous marine mammals. Oceanogr. Mar. Biol. Ann. Rev. (London), 29: 409-486.

Pierce, G.J., P.R. Boyle and J.S.W. Diack. - 1991. Identification of fish otoliths and bones in faeces and digestive tracks of seals. $J$. Zool. (London), 224: 320-328.
Potoschi, A., P. Battaglia, G. Rossi and M. Triscari. - 2003. Studio sulla crescita e su alcuni aspetti biologici di Hygophum benoiti (Cocco, 1838), Pisces, Myctophidae. Biol. Mar. Medit., 10: 127-137.

Rasmussen, O.I. and J. Giske. - 1994. Life-history parameters and vertical distribution of Maurolicus muelleri in Masfjorden in summer. Mar. Biol., 120: 649-664.

Reichenbacher, B., E. Kamrani, H.R. Esmaeili and A. Teimori. 2009. The endangered cyprinodont Aphanius ginaonis (Holly, 1929) from southern Iran is a valid species: evidence from otolith morphology. Environ. Biol. Fish., in press.

Romeo, T., P. Consoli, L. Castriota and F. Andaloro. - 2009. An evaluation of resource partitioning between two billfish, Tetrapturus belone and Xiphias gladius, in the central Mediterranean Sea. J. Mar. Biol. Ass. U.K., 89: 839-848.

Salvanes, A.G.V. and J.B. Kristoffersen. - 2001. Mesopelagic fishes. In: J.H. Steele, S.A. Thorpe and K.K. Turekian (eds.), Encyclopedia of ocean sciences, 3, pp. 1711-1717. Academic Press.

Salvanes, A.G.V. and B.M. Stockley. - 1996. Spatial variation of growth and gonadal developments of Maurolicus muelleri in the Norwegian Sea and in a Norwegian fjord. Mar. Biol., 126: 321-332.

Santos, M.B., M.R. Clarke and G.J. Pierce. - 2001. Assessing the importance of cephalopods in the diets of marine mammals and other top predators: problems and solutions. Fish. Res., 121-129.

Sinopoli, M., C. Pipitone, S. Campagnuolo, D. Campo, L. Castriota, E. Mostarda and F. Andaloro. - 2004. Diet of young-of-theyear bluefin tuna, Thunnus thynnus (Linnaeus, 1758), in the southern Tyrrhenian (Mediterranean) Sea. J. Appl. Ichthyol., 20: 310-313.

Smale, M.J., G. Watson and T. Hecht. - 1995. Otolith atlas of southern African marine fishes. Ichthyol. Monogr. JLB Smith Inst. Ichthyol, 1(14), pp. 253.

Snedecor, G.W. and W.G. Cochran. - 1967. Statistical Methods, 6th edn., pp. 593. Ames, Iowa, USA, The Iowa State Univ. Press.

Spalletta, B., G. Mento, F. Costa, G. Ammendolia, D. Giordano, D. Capecchi and A. Berdar. - 1995. Importanza dello spiaggiamento nella raccolta di specie ittiche rare ed endemiche dello Stretto di Messina (cenni di parassitosi). Riv. Parassitol., XII (LVI), 2: 279-297.

Springer, A.M., J.F. Piatt, V.P. Shuntov, G.B. Van Vliet, V.L. Vladimirove, A.E. Kuzin and A.S. Perlov. - 1999. Marine birds and mammals of the Pacific Subarctic Gyres. Progr. Oceanogr., 43: 443-487.

Tortonese, E. - 1970. Osteichthyes (Pesci ossei). Parte prima. In: Calderini (ed.), Fauna d'Italia, X, pp. 565. Bologna.

Tuset, V.M., A. Lombarte and C.A. Assis. - 2008. Otolith atlas for the western Mediterranean, north and central eastern Atlantic. Sci. Mar., 72S1: 7-198.

Valle, C., J.T. Bayle and A.A. Ramos. - 2003. Weight-length relationships for selected fish species of the western Mediterranean Sea. J. Appl. Ichthyol., 19: 261-262.

Vercelli, F. - 1925. Crociere per lo studio dei fenomeni dello Stretto di Messina. I. Il regime delle correnti e delle maree nello Stretto di Messina, pp. 209. Commissione Internazionale del Mediterraneo, Venezia, Off. Grafiche Ferrari.

Waessle, J.A., C.A. Lasta and M. Bavero. - 2003. Otolith morphology and body size relationships for juvenile Sciaenidae in the Río de la Plata estuary (35-36 S). Sci. Mar., 67: 233-240.

Watanabe, H., T. Kubodera, T. Ichii and S. Kawahara. - 2004. Feeding habits of neon flying squid Ommastraphes bartramii in the transitional region of the central North Pacific. Mar. Ecol. Progr. Ser., 266: 173-184.

Whitehead, P.J.P., M.L. Bauchot, J.C. Hureau, J. Nielsen and E. Tortonese (eds.). - 1984-1986. Fishes of the north-eastern Atlantic and the Mediterranean. UNESCO, Paris.

Williams, T. and B.C. Bedford. - 1974. The use of otoliths for age determination. In: T.B. Bagenal (ed.), The ageing of fish, pp. 114-123. Surrey, England, Unwin Brothers.

Wyllie Echeverria, T. - 1987. Relationship of otolith length to total length in rockfishes from northern and central California. Fish. Bull., 85: 383-387.

Scient. ed.: M.P. Olivar.

Received September 1, 2009. Accepted January 14, 2010.

Published onlline June 7, 2010. 